\title{
Tropical Darwin on Screen: Critiquing national values using urban frontier tropes in Charlie's Country and Last Cab to Darwin.
}

\section{Gemma Blackwood}

Charles Darwin University, Australia

\begin{abstract}
Australia's northern-most tropical city of Darwin has a strong presence in the domestic and international touristic imagination as a tropical escape destination - a small city poised on the edge of outstanding natural beauty yet in national cinematic representations Darwin is often presented as a frontier zone, whether these tropes are pivoted around culture or nature. I would like to take up this idea of the city of Darwin as special and distinctive in the national imaginary that is discernible in recent Australian cinema, an idea that I show extends to the city's representation in theatre and literature. This paper performs a close textual reading of the city's recent representation in two high profile Australian feature films, Charlie's Country (Rolf de Heer, 2013) and Last Cab to Darwin (Jeremy Sims, 2015). These are films that employ compassionate, humanistic themes, each maintaining a strong focus on main characters who find themselves both marginalized and neglected within the broader mechanisms of Australian society: hence each film is simultaneously performing the secondary work of critiquing Australian culture. In both films, I show how the tropical city of Darwin operates as a space of difference, but unlike the contemporary tourism marketing that simplistically brands the region as a "site of desire", here we find two unique critiques of Australian law and society that work to show the ethical frontiers of legislation and of human sovereignty.
\end{abstract}




\section{Introduction}

I

n July 2007, the high-profile Australian film director Baz Luhrmann travelled to tropical Darwin with Fox Studios to shoot segments of his epic war film Australia (2007) set in the Northern Territory during World War II. Ironically, it was the town of Bowen in northern Queensland that was the key production site for the majority of the film's "Darwin" locations, which included vital scenes such as the first kiss between the two protagonists, the vivid dramatization of the Japanese bombing of the city in 1942 and its fatal aftermath ("Big-budget film", 2007). Nevertheless, the production team and the Australian stars of the film, Hugh Jackman and Nicole Kidman, travelled further north to the real Darwin so they could film a cattle-droving scene at the historic Stokes Hill Wharf ("Luhrmann's epic", 2007). It was noted that the scene could have been shot for a quarter of the expense if it had been filmed in a studio in the film-making hub of Lurhmann's home town Sydney ("Territory welcomes Baz", 2007). Yet despite the capability of computergenerated imagery to create a staged version of the city - and it was certainly used to stage many of the spectacular attack scenes in Australia - Luhrmann chose to include what one might call an "authentic" or "real" representation of the city of Darwin in the film. Part of his reasoning for this costly decision was the need to show off the distinctive appeal of the tropical city on screen to an international audience: to show an aspect of the city that was both "real" and "special". His reasons for this perceived singularity come down to the city's twin identity as an "outback" city and gateway to south-east Asia. He noted that:

The pearl divers to the cattlemen to the sense of the great outback, and yet north is Asia: all of those things that make Darwin particularly special, they're very real ("Territory welcomes Baz", 2007).

This mention of the Australian interior and Darwin's position as a gateway to Asia is actually a common way of representing Darwin's exceptional qualities (Carleton, 2008). Certainly, the city has a strong presence in the domestic and international touristic imagination as a tropical escape destination (Russell, 2016. p.97). It is often posed as: the small city poised on the edge of sublime natural beauty; the hottest capital city in Australia and a winter wonderland for southern and international visitors during the mid-year dry season; the city with the largest proportion of Indigenous Australian citizens (Lea, 2014, p.187); a strategic military centre and the nucleus of Northern Australian security; and the closest Australian city to the urban centres of South-East Asia. Recently, Michelle Lobo has noted some other key reasons by which the city of Darwin has come to be known: 
Within the popular imagination, today, multiple narratives of this small northern city co-exist. It is a tropical multicultural paradise with Asianstyle open-air markets, a creative city with arts practitioners, a remote northern city with redneck racism, a carceral city with prisons/detention centres and a multicultural city with a transient 'fly-in/fly-out population' (2018, p.627).

In her book Darwin, Tess Lea points to the city's connection to nature as one of its unique distinguishing features: "Darwin is a place where confrontations with wild nature are not occasional and freakish, but perennial and expected. This matters" (2014, p.187). For Lea, the city's national representation is still deeply linked with the devastation unleashed by Cyclone Tracy in 1974, a catastrophic event that saw the city gaining national attention. Meanwhile, Jon Stratton in his essay "Deconstructing the Territory" suggests that cyclones that disfigure the urban network of Darwin are regularly described culturally as intrusions of an "invasive Other" (2014, p.45), helping to further the idea that destructive non-Australian events intrude into national space via Darwin "from beyond the place constituted as a frontier" (2014, p.45). Again, this perspective understands the city as a unique and distinctive location, a place that often moves into a symbolic reality, although one that traverses the borderlands of national identity, as Stratton notes:

Darwin, then, and the Northern Territory, retain their position on the limit of Australia's discourse both as different and as the site of desire (Stratton, 1989, p.54).

I would like to take up this idea of the city of Darwin as "special", "different" and distinctive in the national imaginary that has been created particularly within recent Australian cinema, an idea that extends to the city's representation in theatre and literature. Here, I will perform a close textual reading of the city's recent representation in two high profile Australian feature films, Charlie's Country (Rolf de Heer, 2013) and Last Cab to Darwin (Jeremy Sims, 2015). These are films that employ compassionate, "humanistic" themes (Aveyard, Moran \& Vieth, 2018, p.156), each maintaining a strong focus on main characters who find themselves both marginalized and neglected within the broader mechanisms of Australian society; hence each film is simultaneously performing the secondary work of critiquing Australian culture more broadly. In both films, the tropical city of Darwin does operate as a space of difference, but unlike the contemporary tourism marketing that simplistically brands the region as a "site of desire", here we find two unique critiques of Australian law and society that work to show the ethical frontiers of legislation and even of human sovereignty. 
When Australian feature films portray Darwin it is clear that they take on heavy symbolic significance, perhaps more so than films that are produced in major Australian cities, precisely because "Darwin films" are so rare to appear on Australian screens. Darwin is infrequently depicted in national cinematic screen fiction. Undoubtedly, this is in part due to a range of socio-economic, political and cultural factors: the city's long distance from filmmaking hubs in south-eastern Australia; the small population, which means that the likelihood of local Darwinbased filmmakers and storytellers are comparatively rare; and the financial costs of producing and filming in Darwin as a city in Northern Australia. Films that are set in Darwin are often documentaries aiming to capture realities of northern existence, whether that be life for first nations drag queens (Black Divaz, 2017), or life in regional communities as depicted in Molly Reynolds' Another Country (2015), which was made simultaneously to Charlie's Country and could be understood as a companion film to the drama. While "regional" capital cities such as Hobart and Perth are also infrequently depicted fictionally on the silver screen, Darwin is unique as a tropical city, carrying a potent range of cultural meanings that link the city to the nation's policing of its northern borders, its regional multiculturalism and of course to constructs of national identity.

\section{Darwin and the Literary Frontier}

To date, there has been no broader survey of the representational themes of films set in Australia's most northernmost city. As part of this paper's literature review, because of a relative lack of research on the broader history of Darwin-focussed cinematic representation, I have examined the research on the narrative representation of Darwin in both film and literature to contextualise my contention about the continuance of a frontier theme in the newer films. In National Fictions: Literature, film and the construction of Australian narrative, Graeme Turner contends that it is sometimes necessary to perform a cross-media analysis of narratives to gain a stronger understanding of national themes than what would come from the focus on just one medium (1986, p.1). This is the case for researching regional narratives set in Darwin. Indeed, discussions about the representation of Darwin in feature films are usually brief, contained in analyses of individual films that have been set in the region. Still, the use of Darwin as a frontier appears repeatedly in these separate analyses. For example, Felicity Collins and Therese Davis have argued that Darwin serves as a frontier between modernity and traditional Arnhem Land lifestyle for the young Yolngu male protagonists of Stephen Johnson's 2002 film Yolngu Boy, which proves to have tragic consequences for one of the central characters unable to operate across both worlds (2004, p.90). Jane Stadler, Peta Mitchell and Stephen Carleton, writing about the representation of the region in the 
historical epic film Australia (which includes the remote city of Darwin), suggest that the film:
...operates as a synecdoche for the country more broadly as well as embodying a quintessential sense of Australianness. Luhrmann's film at once exploits, gives sustenance to, and parodies this cliché of the therapeutic and national identity-forming capabilities of the Outback (2016, p.35).

The researchers suggest that the film functions as a parody of the outback film because it demonstrates self-awareness of this trope in Northern Territorian/ outback literature.

Perhaps because of the historical difficulty of access to the region for a national population primarily centred around the south-eastern seaboard, and the regions "tropical" status, the Northern Territory and the city of Darwin occupy a special place in Australian-focussed travel writing and literature, from Jeannie Gunn's We of the Never Never (1908) to Ernestine Hill's The Great Australian Loneliness (1937). For example, writing more broadly on literature set in the Northern Territory as a whole including arid central Australia as well as the tropical north - Mickey Dewar suggested that the region is seen as:

...both a geographic and political entity distinct from the rest of Australia and as a place with its own cultural and mythic values.... The Territory represents a frontier to Australians, in the sense that it is seen as quintessential of a national experience (1997, pp. $x-X I)$.

Looking at popular fiction and journalism, Mitchell Rolls and Anna Johnston have shown how Darwin and the Northern Territory were featured prominently in the popular twentieth century middlebrow travel magazine Walkabout (1934-1974), an enduring text that repeatedly provided the opportunity for its readers to vicariously travel to parts of the country that were hard to visit in real life for financial and infrastructural reasons (2016, p.15). Therefore, when one examines Darwin's representation in literary narratives - both in popular and lesser-known literature - it is clear that the city and the northern tropical "top end" of Australia are often cited as "special" or exceptional places, and often even perform roles as representational stand-ins for the Australian continent. Stephen Carlton has suggested that the frontier appears repeatedly in the theatre set in the city: 
It is interesting to see Darwin being consistently troped as the capital of Australian Frontier Land so many years after the representations in theatre and literature first occurred. Bedford's White Australia, Masson's An Untamed Territory and Herbert's Capricornia can all be seen as part of a continuum of mythologisation of the northern capital.... The city's vibrant and, at times, problematic, politically charged multi-racial present can be viewed as a palimpsest for the romanticised recollection of Old Darwin (2008, p.65).

Arguably, this is very different than the representation of other Australian capital cities in Australian literature. Usually, the large Australian city operates as a discrete and "modern" oppositional space to the pastoral and "natural" worlds (Torre, 2017, p.1). However, as Stephen Torre, examining the representation of tropical urban space in Australian literature, has noted that in much of the writing about "urban areas in the tropics" [in an Australian context], the city-country binary does not operate as in other urban literature"; he suggests that in the tropics - of which Darwin is one of the most recognisable urban centres - the "urban and rural are often intermingled in an unstable symbiosis" $(2017, \mathrm{p} .1)$. Torre argues that the typical representational tropes of urban identity that are analysed in Australian literary studies - such as the figure of the flâneur moving through postcolonial space, the city as a modernist and postmodernist space, or as industrial sites contesting relationships between traditional cultural configurations - need rethinking when analysing how the cities and towns of Northern Australia have featured in Australian literature. Similarly, turning to the portrayal of cities in Australian cinema, little work has been completed on the representational differences and inconsistencies of the tropical city in Australian cinema.

Before moving on to the analysis of the two films, it is important to note that the way in which tropical locations are represented also adheres to broader tropes in Western literary culture, problematically linked to histories of colonisation and cultural appropriation, and extending outside of the Australian context. Barbara Creed has written of the long history of tropical thinking from a Western framework, which surely still impacts upon interpretative frameworks of contemporary western cinema from a range of different national contexts. Creed notes that ideas about the tropics had:

...its origins in classical times, others have represented the tropics as a deeply uncanny zone where familiar and unfamiliar coalesce. It is as if the heat and intensity of the tropics has liquefied matter until normally incommensurate forms are able to dissolve almost imperceptibly into each other. In this process the boundaries between different systems of thought, ideas and ethics similarly 
dissipate, creating a space for new and often subversive ideas to flourish (2001, p.131).

Undoubtedly, this idea of the "deeply uncanny zone" could be applied to many of the narratives of feature films on Darwin, and even to the concept of the "frontier" itself: a space that sees a confrontation between diverse cultural value systems, which could also be characterised as a familiar/non-familiar space.

Another Western trope in tropical representation - both literary and cinematic - is its position as a holiday destination and an "escape" from the real world. This has been outlined by Chua Huat, who suggests:

One mode of western imagination of the "tropics" is as a place of "romance", never without blue sky, light clouds and gentle breeze that sways the trees. It is therefore a place of "escape" from life in the West, be it from the drudgery of the mundane or from a past that demands forgetting $(2008$, p.4).

Darwin certainly uses these connotations in its self-marketing and tourism campaigns as it targets "southerners" from the major Australian cities. In the films that we examine here, I show how a sense of escape is used ironically in both of these films - particularly through the main protagonists - to demonstrate the gap between touristic fantasy and lived reality. Therefore, a study of Charlie's Country and Last Cab to Darwin could help to perform useful work for larger questions about the continuance of a frontier theme in Australian cinema and literature, an important question for thinking about Darwin's position as a tropical cultural city. At the time of writing, Charlie's Country and Last Cab to Darwin are certainly the most high profile fictional film productions that have been set in Darwin in the last five years, which can be measured in terms of critical reception and the accessibility of the films both through theatrical release and subsequent video/online distribution. Succeeding to reach both national and international markets, both films received favourable critical reviews upon release and their respective releases each started conversations and debates about national issues, especially in relation to the politics of Indigenous Australians (Charlie's Country) and the ongoing debate for euthanasia reform for the country's terminally ill patients (Last Cab to Darwin).

In both films, the city of Darwin is represented as unique or distinct from the rest of Australia for a range of social, cultural and political reasons: in fact, in both films a frontier between disparate social values and attitudes seems to be set in place in the 
city, which suggests that key tropes are perpetuated in Australian cinema about Darwin but are used for a range of purposes. I have selected these two films because they are recent releases and they both draw upon social-realist themes, as each examines the cultural and socio-political impacts connected to a "real life" legalpolitical amendment that has taken place in the Northern Territory. In Charlie's Country, the narrative is framed around the Northern Territory National Emergency Response of 2007 (often referred to in shorthand as "the intervention"), which saw Prime Minister John Howard's Federal government of the time respond to reports of child sexual abuse and neglect by the sudden introduction of changes such as increased law enforcement, and alcohol restrictions onto remote Indigenous communities in the Northern Territory. The intervention was a controversial political move that was highly criticised for the impact that it had on regional communities. It was often interpreted as a last ditch attempt for the Howard government to consolidate political power (they lost power later that year), and it has been heavily criticised for its lack of consultation with local Indigenous community leaders and traditional owners. Worse, criticism of the intervention suggested that the reports of sexual abuse were fabricated and that the motivations for the changes lay in attempts to control disputed territories. Hence, the film has been interpreted as a comment upon the difficulty of life for Indigenous citizens during this period of intervention in the Territory, even if the name of the political response is never specifically mentioned in the film (Herche, 2017, p.235). Marguerite O'Hara suggests that the film was able to use the individual story of the older Yolgnu man, Charlie, in a political and educational way to publicise the broader real life issues that exist for Australian Indigenous communities in the post-Intervention era, as she argues:

While this film is the story of Charlie's struggles to live well, it is also the story of many Indigenous Australians, particularly those living in more remote areas who suffer similar indignities and difficulties to Charlie. It makes the politics and the statistics personal, encouraging us to empathise with the difficulties faced by many Indigenous Australians today (O'Hara, 2014, p. 3).

By doing this, the film needs to draw attention to the city's difference to other parts of Australia: performing the city as an "invasive Other" (to use Jon Stratton's language) means that an audience might find the treatment of Charlie even more shocking.

In the second film, the story of Last Cab to Darwin - which fits more into the category of a three-act "comedy-drama" (Dolgopolov, 2015, p.69) than as pure social-realist drama - is centred on a newly introduced euthanasia law allowing assisted suicide in the Northern Territory, which leads Rex to take a cross-continental road trip to its capital city to take advantage of the unique regulation. Again, the film is based upon 
historical reality: in 1995, euthanasia had been legalised in Darwin and the Northern Territory through the Rights of the Terminally III Act 1995. While the law was quickly voided by the Australian government through the Euthanasia Laws Act 1997, three people were able to die through suicide under the first legislation act, assisted by $\mathrm{Dr}$ Philip Nitschke. While the film was released some twenty years after the real-life historical precedents, recently there has been renewed effort to create new euthanasia laws in Australian States such as in Tasmania (2013), South Australia (2016), Victoria (2017) and New South Wales (2017), so returning to think about the original location where such legislation existed is currently relevant. That it was the Northern Territory that had this unique law helps to perpetuate ideas of "difference" long cultivated by the region, indicating that there are real-world influences on these representations. Let us first turn to the film Charlie's Country to see how a frontier trope emerges, and how it potentially functions to provide a critique of race-based discrimination in Australian society.

\section{Charlie's Country (Rolf de Heer, 2013)}

Blackfella Charlie is getting older, and he's out of sorts. The intervention is making life more difficult on his remote community, what with the proper policing of whitefella laws that don't generally make much sense, and Charlie's kin and ken seeming more interested in going along with things than doing anything about it. So Charlie takes off, to live the old way, but in so doing sets off a chain of events in his life that has him return to his community chastened, and somewhat the wiser (De Heer, 2014, p.2).

As the title of the film suggests, Charlie's Country is about space: it is interested in what "country" means for Indigenous inhabitants of the top end of the Northern Territory, and how that land and space is demarcated and contested by the boundaries of institutionalized power, enacting a divided cultural frontier. Hence, the title is deeply ironic, and it directly questions Charlie's ability to call his home his own "country", which in turn evokes societal problems and the contested nature of Aboriginal land claims since the beginnings of European colonization. The film commences by showing the daily routines and rituals of Charlie's life in a remote Arnhem Land community (in fact, the movie was primarily filmed in Ramingining, the location where lead actor David Gulpilil had spent his childhood). Darwin, the closest city, is a $557 \mathrm{~km}$ road journey from Ramingining and the typical trip between the two destinations takes approximately fourteen hours along the Arnhem Highway. In the wet season, when the flooded plains block the roads, chartered flights are the only viable option. There is a sense in the film that the journey is only possible to the Indigenous characters of the community during emergencies and enforced situations, whereas the white characters can be mobilised to the city due to their 
work roles - for example, the police officer Luke (Luke Ford) moves from Ramingining to Darwin more easily because he is regularly posted to new locations.

In Ramingining, Charlie lives in a small humpy [traditional Aboriginal dwelling] and actively resists the housing assistance offered by what we assume to be the Federal authorities stepping in since the intervention. Happy moments for Charlie are spent hunting and talking with his close friends. But that contentment is undermined by the non-local governing powers, who remove a lot of the typical entertainments of the area, even Charlie's home-made hunting spear. Charlie decides to escape the stifling rules of his community and goes out bush on his own, but the wet weather quickly diminishes his health and he is rescued by his friend Black Pete (Peter Djigirr). A Ramingining doctor realises Charlie's dangerous state of health and tells him "it's off to Darwin with you, my friend". The film has a running time of one hour and forty eight minutes, and the Darwin sequence of the film commences just after the first hour (at 1.02.24), after Charlie is air-lifted to the Royal Darwin Hospital.

It is notable that Charlie's Country has been co-developed by a Darwin-based Indigenous resident (David Gulpili). In the Darwin sequence of the film, we see a critical depiction of the city that highlights inequality and systemic racial injustice perpetrated both through everyday interactions (such as surveillance in shopping areas) and through policing and judicial processes. The creation of a "realistic" depiction of Darwin and the Northern Territory in the film has been an important aspect of the marketing for the film. The film has also been intimately connected to Gulpilil's own arrest and imprisonment at Berrimah Prison, which influenced De Heer to create the film as a form of rehabilitation for the actor. For example, in the official press kit, Rolf De Heer notes the unique writing process that occurred between himself and the lead actor, and that it would be based upon real life events:

The words "...as he does in his own life..." had resonance for me. I felt that if we made it so that David could draw on aspects of his own life in playing a character, if we put that character in situations that David might be familiar with, then David could more easily access or improvise dialogue that would work. He would also be able to keep a better handle on who the character was and where that character had been and was going in any particular part of the story. This was then the second decision, to think constantly about how to give David personal access to the material $(2014$, p.7).

The connection to the film as a social realist document is important; as Samuel Blashki states, "Charlie's Country provides an insider glimpse into a culture that hegemonic Australians would mostly have only seen from the outside" (2014, p.204). The establishment of the film as a part of the social realist genre is an important 
factor for understanding the film's appeal to this "insider glimpse", and the readiness to which the text has been received as a critical evaluation of real-life Australian society. Moran and Vieth note that a typical concern of social realist films is the attention given to marginalized groups, especially those who are "socially invisible" (2006, p.148). Here, the plight of Charlie as marginalized Indigenous citizen becomes key to understanding his trajectory through the city.

This sense of marginalization commences from Charlie's first interaction with a Darwin local, the hospital doctor who notes that he can't pronounce "foreign" names such as Charlie's Indigenous name ("Now I'm a foreigner?" asks Charlie incredulously as he lies in his hospital bed). After visiting his dying friend Fat Albert (Richard Birrinbirrin) another room, Charlie decides to leave before the official discharge date, walking off the hospital site. In this exterior scene, Charlie is the only pedestrian and his body is literally sidelined against the car traffic that is leaving the suburban hospital, further endangered as he crosses the road at a bridge and a passing car beeps for him to move out of the way. Soon after, in the central business district of Darwin, Charlie quickly moves from the commercial centre of town (an ATM in Todd Street Mall) to its physical fringes. Meeting a homeless Indigenous woman called Faith (Jennifer Budukpuduk Gaykamangu), he helps her to buy alcohol from a convenience store, and goes to a local park to camp out and drink with her friends who are "long grassing" in town. This term is complex and has a range of social, political and cultural meanings. In the ATOM guide to the film, Marguerite O'Hara defines "long grassers" as:

....an alternative culture of Aboriginal people who choose to live homeless in the city and surrounds, in a perceived parallel style to how they used to live before white people came $(2014$, p.6).

Long grassing suggests a racial divide in Darwin, and it is a contested form of urban habitation as it often means the occupation of public spaces and parks within city limits. Eviction and destruction of these campsites is regular, depending on the location and uses of the public space. The act of long grassing in Darwin, then, demonstrates different cultural appraisals of urban exterior spaces, and provides a useful way in film for emphasising cultural difference as well as marginalization in the city. In Aboriginal Darwin: A Guide to Exploring Important Sites of the Past \& Present, Toni Bauman explains that long grassing exists as a range of distinctive practices that cannot be pigeonholed into one particular set of meanings or motivations:

Some live in relatively established camps in extended family groups of common origins and others live alone. Still others stay in drinking 
camps composed of Aborigines of many origins and languages...though statistics suggest that most do not drink alcohol. One thing is certain: long grassers cannot be stereotyped (2006, p.xviii).

Moran and Vieth contend that this concern with itinerants or homeless people is in keeping with the concerns of social realist drama: "the more usual environment of the genre is that of the everyday, the commonplace, even the down-at-heel, the seedy, the sordid, the broken, the neglected" (2006, p.153). Therefore, it would be difficult to imagine a more neglected social category in the city than the long grassing population, although simultaneously to relegate this group into the category of "broken" also suggests negative stereotyping of the complex roles connected to what in reality is actually a diverse population. The representational link to long grassing and heavy drinking culture certainly paints a strongly negative image of the activity in Charlie's Country. Arguably, the practice is used allegorically to symbolise ongoing Indigenous disadvantage, as well as to emphasise the problems with the intervention, which drives drinking problems out from the safety of communities into uncaring urban sites that are violent and illicit. In this way, Charlie's new friend Faith is an exemplary victim: trapped in the city, addicted to alcohol, and at the mercy of police raids and surveillance mechanisms. Certainly, the idea of long grassing is problematized in the film, and this negative representation can be used as a signifier of racial violence and control. Hence, the divide caused by a cultural frontier is injected into the film through the construct of an activity that becomes a literal battle ground, which perhaps fails to acknowledge the nuanced natural processes by which cross-cultural contact can take place across the multi-cultural city. It is important to realise that the imposition of the frontier motif is deeply ideological here. Noting the typical setting of social realist cinema, Moran and Vieth suggest that:

Social realism as a genre starts with the ideological universe in which its characters are located. This is the world of the ordinary, the everyday, the mundane, the here and now. Above all, it is the world of the social, the milieu of a community, a setting of ordinariness in which social issues are precipitated and explored, social concerns raised and social themes probed (2006, p.144).

In Charlie's Country, this statement is both accurate and misrepresentative, as the "ordinary" world of Charlie is perhaps extraordinary for the film viewer, unused to life in a remote Australian Aboriginal community or as a marginalized citizen of Darwin in its urban parks. Part of the job of Charlie's Country as a social realist film is to exoticize this ordinariness for the viewer. While Charlie falls in with the long grassers, there is also a division created between him and the other members, who are presented as alcoholics in the film. Samuel Blashki notes the "intimate 
cinematography" that shows Charlie thoughtfully looking around the camp as the other members seem oblivious to their desperate situation (2014, p.204). The melancholic music further emphasises Charlie's dissatisfaction at having moved into this society, even as he wants to help and connect with people such as Faith. The blatant ways by which alcohol is obtained by banned users despite the prohibitions of the intervention legislation demonstrates the futility of the official rules, while the drinking scenes show a profoundly negative and anti-social representation of long grassing community groups (Herche, 2014, p.237).

After the Darwin police routinely destroy the urban campsite, Charlie damages a police car in retaliation and is quickly arrested and incarcerated at Berrimah Prison. Overall, Charlie's Country emphasises the difficult journey that Charlie faces as an Indigenous man in a system that seems to be working against him; the social realist genre helps to draw out the inhumanity of the system and injustice. Charlie's Country shows the citizens of Darwin to be largely indifferent to Indigenous interests, unless Charlie is shown to be in defiance of the law. In the film's Darwin sequence, a lot of the representation of the city focusses on institutionalized spaces - in particular, the hospital, the law court and the prison - an unflattering and un-touristic version of the city, which belies the numerous images of wealth and travel visible on the bodies of the passing tourists in the background. Perhaps because of the film's strong focus on the politics of race and class in the Northern Territory, this is one film that seems to represent Darwin as a distinct urban entity, and it imports European modes of cinematic urban representation (such as temporal and musical references to the city symphony film genre) in order to condemn its hierarchy and cross-cultural conflict. The non-European models for enjoying the tropical city space - crucially represented by the long grassers camping in the city, who seem to be able to understand the complex urban/rural symbiosis of the tropical city - are dismantled by police and fundamentally misunderstood. As Victoria Herche notes, the film is interested on focussing on "the dysfunctionality of the Indigenous community and strongly indicates that the rupture between Indigenous and non-Indigenous Australia has yet to be solved" (2017, p.238). The frontier that is imagined in this film is working to highlight the complex relationship between race and power in the city, which is allegorical for Australian society beyond the permutations of the city.

\section{Last Cab to Darwin (Jeremy Sims, 2015)}

While Darwin and the nearby "Top End" is often depicted as a touristic escape destination in Australian cinema - Rogue (2007), Black Water (2007), Crocodile Dundee (1986) and Dark Age (1987) - in Last Cab to Darwin the city as an escape destination is a little more final. The romantic "dream" tourist destination is 
transformed into the place where dreams can literally end through legally-assisted suicide. Last Cab to Darwin is an adaptation of a play (with the same title) written by Reg Cribb and first performed at the Sydney Opera House in 2003. The newer film adaptation stars Michael Caton as key protagonist Rex McCrae, an ailing taxi driver in Broken Hill who receives a diagnosis of terminal stomach cancer with just three months to live. The story was inspired by the true story of Max Bell, who drove from Broken Hill to Darwin in the early 1990s with the aim of ending his life due to terminal illness. In Bell's case, he was unable to receive assistance due to legal snags, and was forced to return home to die (Byrne, 2016, p.60). The loose film adaptation introduces a romance storyline here to account for this return; thus Rex actively chooses to decline the assisted suicide and decides to return home to his lover Polly, passing away in her arms on the porch.

In the film, Rex's diagnosis coincides with the media notoriety of changing Northern Territory legislation about the introduced euthanasia laws, due to the work of a pioneering euthanasia advocate Dr Farmer (Jacki Weaver). In Broken Hill, his mate at the pub remarks:

Still this euthanasia thing up in the Territory but now it's official, so if you know for sure you're going to kark it - you reckon you've had enough you can just ask her to put you out of your misery.

Rex tries to phone Dr Farmer but cannot reach her. He finally gets to speak to her on talk-back radio and decides to travel to Darwin to meet her. He drives his vehicle his bright yellow Broken Hill taxi cab - through outback central Australia, via Maree and Oodnadatta, Alice Springs, Daly Waters and on up the Stuart Highway to Darwin. On his road trip, Rex meets two significant characters who end up aiding his quest. The first is a young man from Oodnadatta called Tilly (Mark Coles Smith). Tilly is an Indigenous man and a larrikin figure down on his luck. While he mentions a wife and children, in the film they are conspicuously absent. Tilly has gotten into trouble in Oodnadatta, hence Rex's road trip to Darwin helps the young man to escape his immediate problems. It turns out that he has great talent playing AFL rules football, and a coach in Darwin notes he has the potential to become a "superstar" if he could apply himself and give up the drinking. He demonstrates great charisma, with intuitive skill at performance (when he plays for the Daly Waters tourist crowd), which assumedly will also help his renown were he to try out the football career option.

The second key character that Rex meets is Julie (Emma Hamilton), a young British woman taking some time in Australia to get away from a stressful nursing career in London. Having already travelled around the continent, Julie has been working as a 
barmaid in Daly Waters when Rex and Tilly stop by. Ironically, Julie's break from the health profession disappears quickly, as she agrees to provide palliative care to Rex in Darwin so he can avoid a hospital stay.

As the title of the film suggests, Darwin is the culmination of the road trip narrative and the place where Rex should be able to end his life through state assistance. However, despite the work of Dr Farmer, there have been delays and "grey areas" connected with the legislation, and Rex finds himself becoming sicker as he waits for clearance from a range of medical professionals. For Rex, Tilly and Julie, Darwin becomes a place of reckoning: Rex finally understands the strength of his relationship with Polly and ultimately decides he wants to return to her before he passes away; Tilly needs to overcome his antisocial drinking problem or else he will lose his final chance at a football career and a happy family life; and Julie realises that her life calling is in the nursing industry and that she should cease her escapism and return to London.

As in Charlie's Country, long grassing is used negatively in the film; especially so when Tilly quits football after a couple of weeks and disappears into the suburban fringes on a drinking bender. Tilly's new football coach tells Rex and Julie to look out for him "in the long grass", which perhaps symbolically means to look for the various spaces in the city where there is urban Indigenous camping and drinking, as there is no single place where this kind of activity is enacted in the city. When Rex and Julie find him, as in Charlie's Country it is an overwhelmingly negative representation. Tilly says that he is happy, and that here he is able to connect with Indigenous folk from the region, but these relationships are ultimately depicted as superficial. This evokes an earlier scene at the Todd River campsite in Alice Springs, when Tilly's countrymen openly mock him for his drunken stupor, which leads him to quit alcohol until the Darwin relapse. The efforts of Rex's involvement aggravate his cancer symptoms, and he ends up collapsing and being rushed to the hospital. In consequence, Tilly decides to sober up, mustering the will to quit alcohol again and to recommence his football training. In the film, and the final scene of Tilly shows him preparing for his first football game, the stands filled with fans, potentially foreshadowing his fame if he continues to train. The importance of individual accountability and self-determination undermines the potential critique of societal inequality that is more present in Charlie's Country; in Last Cab to Darwin, the ability to move beyond family circumstance and to exercise agency is a recurring concept throughout the film.

Darwin has huge symbolic significance in relation to Rex's own family story. Rex mentions to Polly that his mother, who had also grown up in Broken Hill, had wanted 
to travel to Darwin when she was a young woman. She had set out travelling across country and stopping at Daly Waters, the place where she meets her future husband (Rex's father). Rex notes that his mother had wanted to reach Darwin so that she could "see the sea", which as it turned out she would actually never have the chance to achieve as she became pregnant with Rex and returned to her home town of Broken Hill, never reaching the coast before her death. Rex's father followed his new romantic love to Broken Hill, but became depressed after the move, eventually dying painfully from a lung disease exacerbated by his mining career. Rex scrutinizes old photographs of his parent's stay at Daly Waters, seeing in the pictures his parents at their happiest. Therefore, his own cab trip to Darwin has become an opportunity for him to visit this key place of his own origin story (Daly Waters is $600 \mathrm{~km}$ south of Darwin). For Rex travelling to Darwin represents overcoming a life of unfulfilled dreams and acquiring a new sense of agency; moving beyond the limited opportunities received in life, and demanding new experiences. Even the act of arriving in Darwin means that Rex has succeeded in fulfilling a dream that apparently is inherited from his mother: he notes that he had never seen the sea as he gazes with wonder over a golden sunset on the Arafura Sea.

In Broken Hill Rex has had an unacknowledged relationship with his neighbour, who is an Indigenous woman called Polly (Ningali Lawford). The film hints that the relationship has remained unnamed between them due to residual feelings of cultural difference, which in the film manifests as informal but still fixed boundaries held between indigenous and non-indigenous communities in Rex's hometown. If Broken Hill is represented as a segregated town - literally "broken" across cultural groups - in his work role as a taxi driver, Rex is able to transgress spatial boundaries and mix with a range of diverse patrons across town without commentary. Small visual details, such as Rex removing his hand from Polly's when another neighbour walks past, show that Rex shies from any public acknowledgement of the relationship and the commitment that might come from a legitimate relationship. To Dr Farmer, he calls himself "single" and suggests he has no family or deep ties in order to push his case for assisted suicide.

We see a secondary frontier emerging in this film - a blurring of the boundaries of Australian law and ethical principles - as in 1995-1996 for a very brief period it was technically legal to book a medical euthanasia in Darwin, and a few assisted deaths took place (Bramstedt, 2015, p.725). Hence, in Last Cab to Darwin, the city symbolises a reflective space. Its literal spatial ending of the continental land mass also indicates an ending of life, law and possibly even a loss of ethical boundaries for example, Dr Farmer is presented as being obsessed with getting the law changed, rather than checking in on what Rex's real desires might be. There is a sense of ambivalence towards euthanasia in the film that while arguably being an in- 
built critique, perhaps also allows a cultural space for the circulation of key debates around the controversial laws. Hence, while Charlie's Country seems to be an indictment of the intervention system and its impact on indigenous communities, Last Cab to Darwin suggests that the protagonists undergo journeys where they can take chances, and in so doing, open up the sense of the "frontier" and create new kinds of contact zones where change and growth could occur.

\section{Conclusion}

There are notable similarities between Charlie's Country and Last Cab to Darwin; for example, both of the films maintain a strong focus on the journey of a senior male protagonist, who meets people along the way in line with the quest narrative. Both films also show the protagonists leaving their rural and non-metropolitan "home" for Darwin: Charlie is forced to leave the Indigenous community of Ramingining, Arnhem Land in Charlie's Country, and Rex drives out of the New South Wales town of Broken Hill in Last Cab to Darwin. As I have shown, both protagonists need to leave their home for health-related reasons: Charlie is air-lifted to the Royal Darwin Hospital after contracting a serious respiratory illness and Rex is terminally-ill with stomach cancer, travelling north for medical assistance to die. In both films, the audience "arrives" in the city of Darwin with the protagonists and therefore is forced to see the city through the perspective of the traveller or visitor, which is perhaps in keeping with the touristic version of the city long retained by national visitors, and to make ironic the western tropical trope of the "escape".

Of course, there are also key differences between the films. In Last Cab to Darwin, the city is completely exotic to Rex - he had never seen the sea before - and the film often features touristic and sublime attractions of Darwin, especially featuring lush green waterholes (Berry Springs Nature Park) and tropical sunsets from the East Point cliffs. Meanwhile, in Charlie's Country a less touristic version of Darwin materialises; at least, the version of "sight-seeing" tourism that is connected to Western epistemology. Charlie's Darwin is the marginal space of the Indigenous "long grassers", homeless Indigenous itinerants who camp out in the city's urban parks and reserves.

Perhaps the greatest difference in the films comes down to the relative freedoms of the protagonists. In Charlie's Country, Charlie's actions are largely controlled by various local and federally-enforced laws that regulate his consumption of alcohol, travel and choice of accommodation. In many ways, the film performs an indictment of ongoing colonial surveillance structures in Darwin, where non-Indigenous locals are posed as either oblivious to the damaging politics or else they are unwittingly 
complicit by helping to perpetuate the system's status quo. By contrast, in Last Cab to Darwin, terminally-ill Rex is shown to have a much greater level of personal sovereignty. Although it is done illicitly by a friend, Rex is even given control of the laptop that could administer a fatal dose of medication should he choose to die.

Compellingly, both films enact the idea of the tropical city of Darwin as unique and different. Whether this difference is represented as a frontier of opportunity, or a zone of confinement, it nevertheless indicates the persistence of Darwin as a symbol of ambivalence, conflict and possibility when used in Australian cinema, especially when used in social realist narratives.

\section{References}

Aveyard, K., Moran, A. \& Vieth, E. (2018). Historical Dictionary of Australian and New Zealand Cinema $\left(2^{\text {nd }}\right.$ ed.). Lanham, USA: Rowman \& Littlefield.

Bauman, T. (2006). Aboriginal Darwin. A Guide to exploring important sites of the past \& present. Canberra, AU: Aboriginal Studies Press.

"Big-budget film puts Bowen on the map" (2007). Sydney Morning Herald. Retrieved from: https://www.smh.com.au/news/queensland/bigbudget-film-puts-bowen-on-themap/2007/06/07/1181089197279.html

Blashki, S. (2014). Charlie's country. Alternative Law Journal, 39(3), 204.

Bramstedt, K. (2015). Last Cab to Darwin. Journal of Bioethical Inquiry, 12(4), 725-726.

Byrne, M. (2016). The Outback Within: Journeys into the Australian Interior. Newcastle upon Tyne, UK: Cambridge Scholars Publishing.

Carleton, S. (2008). Darwin as the Frontier Capital: Theatrical Depictions of City Space in the North. Australasian Drama Studies, (52), 52-68.

Collins, F. \& Davis, T. (2004). Australian Cinema After Mabo. Cambridge, UK, Cambridge University Press.

Creed, B. (2001). Tropical Malady: Film \& the Question of the Uncanny Human-Animal. eTropic: electronic journal of studies in the tropics 10, 131-140. DOI: http://dx.doi.org/10.25120/etropic. 10.0.2011

De Heer, R. (2014). Director's Statement: The Story of Charlie's Country by Rolf De Heer. Charlie's Country Australian Press Kit, Vertigo Productions, 4-15. Retrieved from: https://www.vertigoproductions.com.au/downloads/charlies_country_australian_press kit.pdf

Dewar, M. (1997). In Search of the 'Never-Never': Looking for Australia in Northern Territory Writing. Darwin, AU: Northern Territory University Press.

Dolgopolov, G. (2015). Odyssey across the Outback: Jeremy Sims' 'Last Cab to Darwin'. Metro Magazine: Media \& Education Magazine, 186, 68-73.

Herche, V. (2017). Reassessing Indigenous Self-Determination in Rolf de Heer's Charlie's Country (2014). In Baehr, E. and Schmidt-HaberKamp, B. (eds) 'And there'll be NO dancing': Perspectives on Policies Impacting Indigenous Australia since 2007. Newcastle upon Tyne, UK: Cambridge Scholars Publishing, pp. 228-242.

Huat, C. B. (2008). Tropics, city and cinema: Introduction to the special issue on cinematic representation of the tropical urban/city. Singapore Journal of Tropical Geography, 29, 1-7.

Lea, T. (2014). Darwin. Sydney, Australia: NewSouth Books. 
Lobo, M. (2018). Re-framing the creative city: Fragile friendships and affective art spaces in Darwin, Australia. Urban Studies, 55(3), 623-638.

"Luhrmann's epic moves to Darwin". (2007). The Age. July 2 2007. Retrieved from: https://www.theage.com.au/news/film/luhrmanns-epic-moves-todarwin/2007/07/01/1183228968331.html

Moran, A. \& Vieth, E. (2006). Film in Australia: An Introduction. Port Melbourne: Cambridge University Press.

O'Hara, M. (2014). Charlie's Country Study Guide. ATOM Study Guide.

O'Regan, T. (1996). Australian National Cinema. London, UK: Routledge.

Rolls, M. \& Johnston, A. (2016). Travelling Home: Walkabout Magazine and Mid-Twentieth Century Australia. London, UK: Anthem Press.

Russell, L. (2016). Darwin, a city on the edge. Postcolonial Studies, 19(1), 97-99.

Rutherford, L. (2004). Negotiating Masculinities: Yolngu Boy. Metro Magazine, 140, 62-59.

Stadler, J, Mitchell, P. \& Carleton, S. (2016) Imagined Landscapes: Geovisualizing Australian Spatial Narratives. Bloomington, USA: Indiana University Press.

Stratton, J. (1989). Deconstructing the Territory. Cultural Studies. 3(1), 38-57.

"Territory welcomes Baz Luhrmann." (2007) ABC News, July 2 2007. Retrieved from: http://www.abc.net.au/news/2007-07-01/territory-welcomes-baz-luhrmann/85986

Torre, S. (2017) The Tropical Urban Imaginary in Australian Fiction from Thea Astley to Alexis Wright. Conference Paper. Tropics of the Imagination Conference, Singapore, September.

Turner, G. (1986). National Fictions: Literature, film and the construction of Australian narrative. Sydney, Australia: Allen \& Unwin. 